\title{
The Cost Analysis of Network Drug Information Services at Ministry of Health Institutions in Saudi Arabia
}

\author{
Yousef Ahmed Alomi ${ }^{1, *}$, Sultan Mohammed Al-Jarallah ${ }^{2}$ \\ ${ }^{1}$ The Former General Manager of General Administration of Pharmaceutical Care and Former Head, National Clinical Pharmacy \\ and Pharmacy Practice and Pharmacy $R \&$ D Administration, Ministry of Health, Riyadh, SAUDI ARABIA. \\ ${ }^{2}$ Head, Ambulatory Care Pharmacy, Oncology and Hematology Clinical Pharmacist, Pharmaceutical Care Department, Security \\ Forces Hospital, Riyadh, SAUDI ARABIA.
}

\section{Received: 02 October 2018; \\ Accepted: 26 November 2018 \\ *Correspondence to: \\ Dr. Yousef Ahmed Alomi,} The Former General Manager of General Administration of Pharmaceutical Care, Former Head, National Clinical Pharmacy and Pharmacy Practice Head, Pharmacy $R$ \& $D$ Administration Ministry of Health, Riyadh, SAUDI ARABIA. Email:yalomi@gmail.com

Copyright: (C) the author(s),publisher and licensee Indian Academy of Pharmacists. This is an open-access article distributed under the terms of the Creative Commons Attribution Non-Commercial License, which permits unrestricted non-commercial use, distribution, and reproduction in any medium, provided the original work is properly cited.

\begin{abstract}
Objective: To explore analysis cost of network Drug Information Services at Ministry of Health institutions. Methods: It is cost simulation of a 2-months cross-sectional survey of all drug information centers at $\mathrm{MOH}$ Hospitals. Any drug opened and provided services to health care professionals and the public participated in the questionnaire. All type of drug information centers national or regional or local at healthcare institutions including in the survey. All type of hospitals or primary care centers included in the survey (public, pediatric, maternity, psychiatry) included in the study. The survey consisted of two part. Demographics data and the second part included the variable expenses included personal cost, material and supply cost, Fixed expenses including direct cost, non-salary cost and overhead cost. All cost used as United States dollar currency. Results: The survey distributed to sixty drug information centers in total responded forty-six centers, the response rate was $76.66 \%$. The majority of hospitals $11(23.9 \%)$ with (100-199 beds) and 11 (23.9\%) with (200-299 beds). The highest average monthly salary was for the Head of Drug Information Centers (3,160.98 USD) followed by the regular pharmacist (2,909.80 USD) and Clinical Pharmacist (2,823.53 USD). The average daily cost of Drug Information Centers was (537.41 USD) and monthly (16,122.3 USD). The most contribution was personal cost 506 USD (94.26\%) Followed by material and supply $14.81(2.75 \%)$ USD and non-salary cost 9.06 USD (1.68\%). Conclusion: The daily cost of consuming of drug information services is high. The number of services should increase and cost avoidance of clinical activities is required to do periodically.
\end{abstract}

Key words: Cost, Network, Drug Information Services, Ministry of Health, Saudi Arabia.

\section{INTRODUCTION}

The drug information centers network in the Kingdom of Saudi Arabia play a potential role in the answering Healthcare Professional and public inquiries..$^{[1]}$ The network participated in the hotline call (937) at Ministry of Health services in the past years. ${ }^{[1]}$ They showed high-cost saving per each call. In the study, the author did not calculate the cost of services of drug information because of the participant shred as additional to their daily activities. ${ }^{[2]}$ Also, in new Saudi vision implementation and with transformation program required to calculate the cost of services ${ }^{[3,4]}$ That is demand for privatization. Several studies around the world published including Inside Saudi Arabia about cost avoidance of drug information services. ${ }^{[2,5-10]}$ However, there is no detail and clarity of cost analysis of Drug Information Services. It seldom to find cost analysis of drug information centers services or foundations in the Kingdom of Saudi Arabia or Gulf and Middle East countries. The objective of the study to explore the cost analysis of drug information centers in Saudi Arabia.

\section{MATERIALS AND METHODS}

\section{Methods}

This is cost simulation of a 2-months cross-sectional survey of all drug information centers at $\mathrm{MOH}$ Hospitals. Any drug opened and provided services to health care professionals and the public participated in the questionnaire. All types of drug information centers national or regional or local at healthcare institutions including in the survey. All type of hospitals or primary care centers included in the survey (public, pediatric, maternity, psychiatry) included in the study. The survey consisted of two parts. Demographics data and consisted of several part questions; Part one: workload of drug information centers, Part two: Cost analysis of Drug Information Centers foundations, Part three: the Cost analysis of drug information activity and Part four: questions about education and training activity of drug information centers. The second one discussed in this study. The cost calculated based on the variable expenses included personal cost, material and supply cost, Fixed expenses including direct cost, non-salary cost and overhead cost. ${ }^{[1]}$ All cost used US dollar currency. All calculation done used an electronic Survey monkey system.

\section{RESULTS}

The survey distributed to sixty drug information centers in total responded forty-six centers, the response rate was $76.66 \%$. The majority of hospitals 11 (23.9\%) with (100-199 beds) and 11 (23.9\%) with (200-299 beds). The majority of hospitals accredited of Saudi Center for Accreditation of Healthcare Institutions (CBAHI) $27(58.7 \%)$ and Saudi Commission of Health Specialties $9(19.6 \%)$ while $11(23.9 \%)$ hospitals not accredited by any organization. Most of the type of drug information centers were adults drug information center $20(43.48 \%)$ and $15(32.61 \%)$ followed by psychiatric drug information centers $5(10.87 \%)$ and pediatrics drug information centers $4(8.7 \%)$ as explored in Table 1 . Among the responders the $43(95.6 \%)$ was 
Saudi and 2 (4.4\%) was non-Saudi. The age distribution (18-40 years) was high value $44(95.7 \%)$. The most educational level of the responders was Bachelor degree of Pharmacy 22 (47.83\%), Doctor of Pharmacy 11 (23.9\%) and Master of Science degree $9(19.57 \%)$. Only $4(10 \%)$ has certified Pharmaceuticals specialties. Most of responders $30(65.2 \%)$ were 1-6 years experience with drug information services and 8 (17.39\%) of Clinical Pharmacy experiences as explored in Table 2 and Table 3. The most equipment available in the Drug Information Center was computers 39 (84.78\%), the internet $37(80.43 \%)$ and offices $35(77.77 \%)$. While most non-available equipment was the iPad, $41(89.13 \%)$ answering machine $38(82.6 \%)$ and $37(80.43 \%)$ laptop as explored in Table 4 . The highest average monthly salary was for the head of Drug Information Centers (3,160.98 USD) followed by the regular Pharmacist (2,909.80 USD) and Clinical Pharmacist (2,823.53 USD) as explored in Table 5. The average daily cost of drug information centers was (537.41 USD) and monthly (16,122.3 USD). The most contribution was personal cost 506 USD (94.26\%) Followed by material and supply 14.81 (2.75\%) USD and non-salary cost 9.06 USD $(1.68 \%)$ as explored in Table 6.

\section{DISCUSSION}

The strategic plan general administration of Pharmaceutical Care at the Ministry of Health in the Kingdom of Saudi Arabia consisted of five strategic goals. ${ }^{[12]}$ The fifth goal related to Pharmaco Economic and Health cost-related issues. The cost analysis of drug information centers party of that is one.

\begin{tabular}{|l|l|l|}
\hline \multicolumn{3}{|l|}{ Table 1: Demographic Hospital Information. } \\
\hline Number of beds at the hospital & $\begin{array}{l}\text { Response } \\
\text { Count }\end{array}$ & $\begin{array}{l}\text { Response } \\
\text { Percent }\end{array}$ \\
\hline$<50$ & 7 & $15.2 \%$ \\
\hline $50-99$ & 6 & $13.0 \%$ \\
\hline $100-199$ & 11 & $23.9 \%$ \\
\hline $200-299$ & 11 & $23.9 \%$ \\
\hline $300-399$ & 4 & $8.7 \%$ \\
\hline $400-499$ & 4 & $8.7 \%$ \\
\hline = or > 600 & 3 & $6.5 \%$ \\
\hline Medical City & 0 & $0.0 \%$ \\
\hline Answered question & 46 & \\
\hline Skipped question & 0 & \\
\hline The hospital accreditation & Response Count & Response Percent \\
\hline ClBAHI & 27 & $58.7 \%$ \\
\hline Joint Commotion the USA & 7 & $15.2 \%$ \\
\hline Canada & 1 & $2.2 \%$ \\
\hline Saudi commission on health accreditation & 9 & $19.6 \%$ \\
\hline Non-accredited & 11 & $23.9 \%$ \\
\hline Answered question & 46 & \\
\hline Skipped question & 0 & $8.70 \%$ \\
\hline The type of drug information center & Response Count & Response Percent \\
\hline General Drug Information Center & 15 & $32.61 \%$ \\
\hline Adult drug information center & 20 & $0.00 \%$ \\
\hline Pediatric drug information center & 4 & $2.17 \%$ \\
\hline Psychiatric drug information center & 5 & $0.00 \%$ \\
\hline Oncology drug information center & 0 & $2.17 \%$ \\
\hline Cardiology drug information center & 1 & \\
\hline Dental drug information center & 0 & \\
\hline Primary health care drug information center & 1 & $46 \%$ \\
\hline Answered question & 0 & \\
\hline Skipped question & & \\
\hline & 46.48 & \\
\hline
\end{tabular}

\begin{tabular}{|c|c|c|}
\hline Nationality & $\begin{array}{l}\text { Response } \\
\text { Count }\end{array}$ & $\begin{array}{l}\text { Response } \\
\text { Percent }\end{array}$ \\
\hline Saudi & 43 & $95.6 \%$ \\
\hline Non- Saudi & 2 & $4.4 \%$ \\
\hline Answered question & 45 & \\
\hline Skipped question & 1 & \\
\hline Gender & Response Count & Response Percent \\
\hline $18-40$ years & 44 & $95.7 \%$ \\
\hline $40-65$ years & 2 & $4.3 \%$ \\
\hline $18-40$ years & 0 & $0.0 \%$ \\
\hline more than 65 years & 0 & $0.0 \%$ \\
\hline Answered question & 46 & \\
\hline Skipped question & 0 & \\
\hline Academic Qualification (s): & Response Count & Response Percent \\
\hline Diploma Pharmacy & 7 & $15.22 \%$ \\
\hline Bsc. Pharm & 22 & $47.83 \%$ \\
\hline M.S & 9 & $19.57 \%$ \\
\hline Msc. Clinical Pharmacy & 6 & $13.04 \%$ \\
\hline Pharm.D. & 11 & $23.91 \%$ \\
\hline Ph.D & 0 & $0.00 \%$ \\
\hline MBA & 3 & $6.52 \%$ \\
\hline Pharmacy Residency Two years (R1) & 1 & $2.17 \%$ \\
\hline Pharmacy Residency one year (R2) & 0 & $0.00 \%$ \\
\hline Fellowship & 1 & $2.17 \%$ \\
\hline Others & 1 & $2.17 \%$ \\
\hline Answered question & 46 & \\
\hline Skipped question & 0 & \\
\hline Total years worked as a pharmacist & Response Count & Response Percent \\
\hline $\begin{array}{l}\text { Board Certified Ambulatory Care } \\
\text { Pharmacist (BCACP) }\end{array}$ & 0 & $0.0 \%$ \\
\hline $\begin{array}{l}\text { Board Certified Critical Care } \\
\text { Pharmacist (BCCCP) }\end{array}$ & 0 & $0.0 \%$ \\
\hline $\begin{array}{l}\text { Board Certified Nuclear Pharmacist } \\
\text { (BCNP) }\end{array}$ & 1 & $2.5 \%$ \\
\hline $\begin{array}{l}\text { Board Certified Nutrition Support } \\
\text { Pharmacist (BCNSP) }\end{array}$ & 0 & $0.0 \%$ \\
\hline $\begin{array}{l}\text { Board Certified Oncology Pharmacist } \\
\text { (BCOP) }\end{array}$ & 0 & $0.0 \%$ \\
\hline $\begin{array}{l}\text { Board Certified Pediatric Pharmacy } \\
\text { Specialist (BCPPS) }\end{array}$ & 1 & $2.5 \%$ \\
\hline $\begin{array}{l}\text { Board Certified Pharmacotherapy } \\
\text { Specialists (BCPS) }\end{array}$ & 1 & $2.5 \%$ \\
\hline $\begin{array}{l}\text { Board Certified Psychiatric Pharmacist } \\
\text { (BCPP) }\end{array}$ & 1 & $2.5 \%$ \\
\hline Non & 39 & $97.5 \%$ \\
\hline Others & 1 & $2.5 \%$ \\
\hline Answered question & 40 & \\
\hline Skipped question & 6 & \\
\hline
\end{tabular}


Table 3: The total years of experience.

\begin{tabular}{|c|c|c|c|c|c|}
\hline Answer Options & Pharmacy Practice & Clinical Pharmacy & $\begin{array}{l}\text { Pharmacy } \\
\text { Administration }\end{array}$ & $\begin{array}{l}\text { Drug information } \\
\text { services }\end{array}$ & Response Count \\
\hline 0 & 2 & 7 & 3 & 3 & 13 \\
\hline$<1$ year & 3 & 5 & 4 & 6 & 16 \\
\hline $1-3$ & 8 & 5 & 9 & 14 & 24 \\
\hline $4-6$ & 17 & 3 & 7 & 16 & 28 \\
\hline$>6$ years & 23 & 5 & 11 & 8 & 29 \\
\hline \multicolumn{5}{|l|}{ answered question } & 46 \\
\hline \multicolumn{5}{|l|}{ skipped question } & 0 \\
\hline
\end{tabular}

\begin{tabular}{|c|c|c|c|c|c|c|c|c|}
\hline $\begin{array}{l}\text { Answer } \\
\text { options }\end{array}$ & 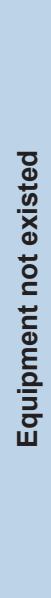 & 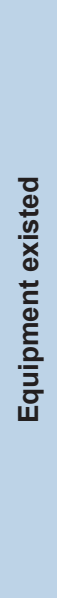 & 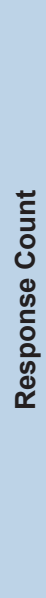 & 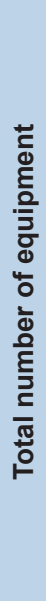 & 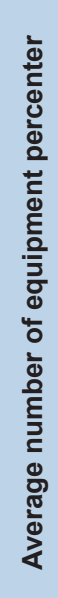 & 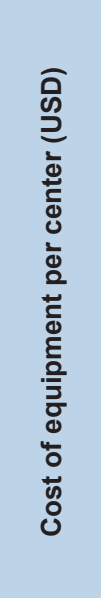 & 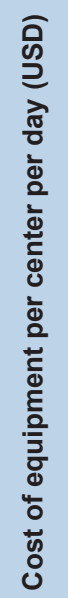 & 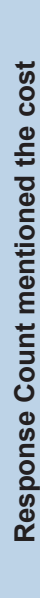 \\
\hline Place & 13 & 33 & 46 & 60 & 1.82 & 15641.60 & 42.85 & 10 \\
\hline Computer & 7 & 39 & 46 & 54 & 1.38 & 928.33 & 2.54 & 24 \\
\hline Laptop & 37 & 9 & 46 & 9 & 1.00 & 311.84 & 0.85 & 14 \\
\hline iPad & 41 & 5 & 46 & 7 & 1.40 & 281.15 & 0.77 & 9 \\
\hline Offices & 10 & 35 & 45 & 42 & 1.20 & 1178.24 & 3.23 & 20 \\
\hline $\begin{array}{l}\text { Landline } \\
\text { telephone }\end{array}$ & 12 & 34 & 46 & 49 & 1.44 & 316.04 & 0.87 & 17 \\
\hline Mobile & 31 & 15 & 46 & 28 & 1.87 & 634.00 & 1.74 & 13 \\
\hline $\begin{array}{l}\text { Software } \\
\text { of inquiries } \\
\text { documentations }\end{array}$ & 21 & 25 & 46 & 39 & 1.56 & 984.61 & 2.70 & 13 \\
\hline Printer and fax & 15 & 31 & 46 & 42 & 1.35 & 257.78 & 0.71 & 21 \\
\hline Copy machines & 21 & 25 & 46 & 26 & 1.04 & 474.86 & 1.30 & 16 \\
\hline $\begin{array}{l}\text { Answering } \\
\text { machine }\end{array}$ & 38 & 8 & 46 & 12 & 1.50 & 165.00 & 0.45 & 8 \\
\hline Internet & 9 & 37 & 46 & 52 & 1.41 & 439.03 & 1.20 & 17 \\
\hline Library & 23 & 23 & 46 & 41 & 1.78 & 5714.49 & 15.66 & 15 \\
\hline
\end{tabular}


Table 5: The monthly salary of staff for drug information centers.

\begin{tabular}{|c|c|c|c|c|c|c|c|c|}
\hline Answer Options & 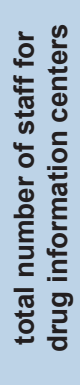 & 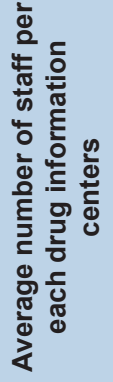 & 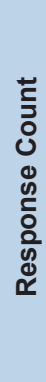 & $\begin{array}{l}\frac{\mathbb{2}}{\pi} \\
\frac{\pi}{\sqrt{0}} \\
\frac{\omega}{\pi} \\
\frac{0}{0}\end{array}$ & 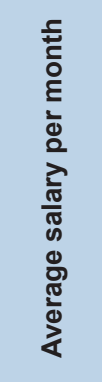 & 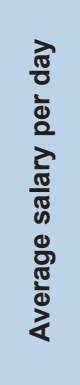 & 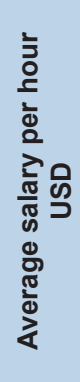 & 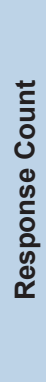 \\
\hline Head of drug information center & 50 & 1.09 & 46 & $129,600.00$ & $3,160.98$ & 143.68 & 17.96 & 41 \\
\hline Clinical Pharmacist & 24 & 0.52 & 46 & $96,000.00$ & $2,823.53$ & 128.34 & 16.04 & 34 \\
\hline Pharmacist & 55 & 1.20 & 46 & $98,933.33$ & $2,909.80$ & 132.26 & 16.53 & 34 \\
\hline Pharmacy technician & 47 & 1.04 & 45 & $70,400.00$ & $2,270.97$ & 103.23 & 12.90 & 31 \\
\hline Secretary & 6 & 0.13 & 45 & $34,933.33$ & $1,126.88$ & 51.22 & 6.40 & 31 \\
\hline Porter & 9 & 0.20 & 46 & $35,733.33$ & $1,152.69$ & 52.39 & 6.55 & 31 \\
\hline
\end{tabular}

Table 6: Cost analysis of drug information center foundations.

\begin{tabular}{|c|c|c|c|}
\hline Type of cost & $\begin{array}{l}\text { Average } \\
\text { monthly } \\
\text { cost }\end{array}$ & $\begin{array}{l}\text { Average } \\
\text { daily cost }\end{array}$ & $\begin{array}{l}\text { Average } \\
\text { hourly cost }\end{array}$ \\
\hline \multicolumn{4}{|l|}{ Personal } \\
\hline Head of drug information center & $3,445.46$ & 156.61 & 19.58 \\
\hline Clinical Pharmacist & $1,468.24$ & 66.74 & 8.34 \\
\hline Pharmacist & $3,491.76$ & 158.72 & 19.84 \\
\hline Pharmacy technician & $2,361.81$ & 107.35 & 13.42 \\
\hline Secretary & 146.49 & 6.66 & 0.83 \\
\hline Porter & 230.54 & 10.48 & 1.31 \\
\hline \multicolumn{4}{|l|}{ Over Head cost } \\
\hline Place & 279.60 & 42.85 & 1.79 \\
\hline Computer & 39.90 & 2.54 & 0.11 \\
\hline Laptop & 7.80 & 0.85 & 0.04 \\
\hline iPad & 4.50 & 0.77 & 0.03 \\
\hline Landline telephone & 9.60 & 0.87 & 0.04 \\
\hline Mobile & 14.70 & 1.74 & 0.07 \\
\hline $\begin{array}{l}\text { The software of inquiries } \\
\text { documentations }\end{array}$ & 22.80 & 2.70 & 0.11 \\
\hline Printer and fax & 9.60 & 0.71 & 0.03 \\
\hline Copy machines & 13.50 & 1.30 & 0.05 \\
\hline Answering machine & 2.40 & 0.45 & 0.02 \\
\hline \multicolumn{4}{|l|}{ Material and Supply } \\
\hline Offices & 42.90 & 3.23 & 0.13 \\
\hline \multicolumn{4}{|l|}{ Non Salary cost } \\
\hline Education and Training & 271.80 & 9.06 & 1.13 \\
\hline \multicolumn{4}{|l|}{ Direct cost } \\
\hline Internet & 13.20 & 1.20 & 0.05 \\
\hline Library & 153.30 & 15.66 & 0.65 \\
\hline Total & $16,122.30$ & 537.41 & 67.18 \\
\hline
\end{tabular}

Also, the new Saudi vision 2030 and strategic health plan discussed that is matter. ${ }^{[4]}$ The author tried to explore the cost of foundation drug information centers services at Ministry of Health in Saudi Arabia. The findings of the study showed that is the primary foundations of drug information centers founded while the advance foundations not available at drug information services because there are precise budgets for Pharmacy departments at each hospital. The head of drug information centers had the highest salary among drug information centers staff because they old in their position and additional bonus got from Ministry of Health. While the lowest salary was a Clinical Pharmacist; because newly employed and they are not specialized or consulting a Clinical Pharmacist. The average daily or monthly cost of drug information centers was high, with most cost came from personal cost because the drug information centers do not use high expense equipment and most of the buildings owned by Ministry of Health. The high percentage of personal cost resemble what reported in the cost of distribution of medication therapy management. ${ }^{[11]}$ It was lower than that reported in the other investigations because they used costly equipment in the other pharmacy services. ${ }^{[13-15]}$ The other finding is difficult to compare with literature because lacking information data. The cost analysis of drug information services was expensive and a lot of activities, performances and services provided to the healthcare professional and public populations to cover the justification of established the services at Ministry of Health Organization in Kingdom of Saudi Arabia. The study first was done in Gulf and Middle East countries and may utilize with transformation programs in the new Saudi Visions 2030. [3,16]

\section{CONCLUSION}

The cost analysis of drug information centers first done at Ministry of Health Hospitals and in the Gulf and Middle East countries. The cost analysis of foundations of Drug Information Services is demanding requirements of the new plan of Ministry of Health and Saudi Vision 2030.

\section{ACKNOWLEDGEMENT}

None.

\section{CONFLICT OF INTEREST}

The authors declare no conflict of interest. 


\section{ABBREVIATIONS}

KSA: Kingdom of Saudi Arabia; MOH: Ministry of Health; CBAHI: Saudi Center for Accreditation of Healthcare Institutions.

\section{REFERENCES}

1. Alomi YA, Mudaiheem HA. National Drug Information Center Services through Ministry of Health Hotline Calling Center (937) in Saudi Arabia. Adv Pharmacoepidemiol Drug Saf. 2016;5(1):1-7.

2. Alomi YA, Almudaiheem HY, Alarnous T, Alshurei S, Alsharafa A, Alzahrani T, et al. Cost-Efficiency of National Drug Information Center Through Ministry of Health Hotline Calling Services (937) in Saudi Arabia: Application of a Mercian Model. Value Heal. 2015;18(7):A735.

3. Government of Saudi Arabia. Saudi Arabia Vision 2030. 2016. Available from: file://C:/ Users/yalomi/Downloads/Saudi_Vision2030_EN (1).pdf

4. Council for Economic Affairs and Development in KSA. National Transformation Program 2020. 2016;113. Available from: http://vision2030.gov.sa/sites/default/files/ NTP_ar.pdf

5. Skoutakis VA, Wojciechowski NJ, Carter CA, Hayes JM, Hudson BL, Martin JA. Drug Information Center network: need, effectiveness and cost justification. Drug Intell Clin Pharm. 1987;21(1):49-56.

6. Lyrvall H, Nordin C, Jonsson E, Alvan G, Öhman B. Potential savings of consulting a drug information center. Annals of Pharmacotherapy. 1993;27(12):1540.
7. Kinky DE, Erush SC, Laskin MS, Gibson GA. Economic impact of a drug information service. Ann Pharmacother. 1999;33(1):11-6.

8. Marrone CM, Heck AM. Impact of a Drug Information Service: Practitioner Hours Saved. Hosp Pharm. 2000;35(10):1065-70.

9. Ponampalam R, Loh CS. Cost benefits of the Drug and Poison Information Centre in preventing unnecessary hospitalisation: The Singapore experience. Hong Kong $\mathrm{J}$ Emerg Med. 2010;17(1):45-53.

10. Brown JN. Cost Savings Associated With a Dedicated Drug Information Service in an Academic Medical Center. Hosp Pharm. 2011;46(9):680-4.

11. Rupp MT. Analyzing the costs to deliver services. Pharm Today. 2011;56-64.

12. Alomi YA, Alghamdi SJ, Alattyh RA. Strategic Plan of General Administration of Pharmaceutical Care at Ministry of Health in Saudi Arabia 2012 - 2022. JPharm Pharm Sci. 2015;1(13):1-8.

13. Alomi YA, Alhadab M, Alotaibi T, Alhaza N, Alassadi N, Alzahrani S, et al. Cost of pediatrics drug therapy services at ministry of health in saudi arabia. Value Healt. 2017;20(5):A34-A34.

14. Alomi YA, Alhadab M, Alotaibi T, Alassadi N, Alhaza N, Alzahrani S, et al. Cost analysis of delivery adult medication therapy services at ministry of health in saudi arabia. Value Healt. 2017;20(5):A33-4.

15. Alomi YA, Fallatah AO. Cost-analysis and forecasting during (2016-2020) of total parenteral nutrition preparations in saudi arabia. In: Value Healt. 2017;20(5):A34-A34.

16. Alomi YA. New Pharmacy Model for Vision 2030 in Saudi Arabia. J Pharm Pract Community Med. 2017;3(3).

Cite this article as: Alomi YA, Al-Jarallah SM. The Cost Analysis of Network Drug Information Services at Ministry of Health Institutions in Saudi Arabia. J Pharm Pract Community Med. 2018;4(4):226-30. 